\title{
Autologous blood transfusion: Standard of care for the 1990s
}

\author{
JOHN R. ZOND, DO
}

The risks of transmission of devastating and sometimes fatal viral infections from homologous blood transfusion have caused concern among patients undergoing elective major surgical procedures. Autologous blood transfusions eliminate the potential risk posed by these viruses. A well-informed primary care physician can help patients undergoing elective surgical procedures to determine whether autologous blood transfusion is an appropriate therapeutic alternative. A well-equipped and certified blood bank will allow patients to donate autologous units while keeping patient risk at a minimum.

(Key words: Autologous blood transfusion, phlebotomy, acquired viral infections, elective surgery)

The possibility of a debilitating or even fatal infectious disease developing as a result of blood transfusion during or after a surgical procedure has caused increasing numbers of patients facing elective surgical procedures to consider autologous blood transfusions. A wellinformed primary care physician can provide the patient with the information needed to make an informed decision regarding autologous blood transfusion.

From the Department of Pathology and Laboratory Medicine, Philadelphia College of Osteopathic Medicine, Philadelphia, $\mathrm{Pa}$, where $\mathrm{Dr}$ Zond is associate professor of pathology.

Reprint requests to John R. Zond, DO, Philadelphia College of Osteopathic Medicine, 4150 City Ave, Philadelphia, PA 19131-1696.

\section{Acquired infections}

Five major viral infections may be acquired through blood transfusions (Table 1): cytomegalovirus (CMV); non-A, non-B hepatitis virus (NANB); the human immunodeficiency virus type 1 (HIV-1); the human T-cell leukemia virus type 1 (HTLV); and the human immunodeficiency virus type 2 (HIV-2).

\section{Cytomegalovirus}

Cytomegalovirus is by far the most common virus transmitted by homologous blood transfusion, because most blood donated in the United States is not routinely tested for CMV. The virus lives in leukocytes and can become active years after initial infection. Although CMV infection poses little or no threat to a healthy person, it can prove devastating to those with a depressed immune system.

\section{Non-A, non-B hepatitis virus}

The NANB virus is more prevalent than the HIV virus with regard to transfusion-related disease. As a result of infection caused by the NANB virus, non-A non-B hepatitis develops. This disease, which accounts for $90 \%$ of the posttransfusion hepatitis cases, has on average a 7 - to 8-week incubation. The range for incubation, however, is wide. The acute stages are less severe than type B hepatitis, but can result in a much more fulminant hepatitis. Approximately half of the persons affected with NANB hepatitis can expect to have elevated liver enzymes up to 1 year after infection. Sequelae range from cirrhosis to hepatoma to chronic active hepatitis, even in the absence of any icteric state. 
Table 1

Viruses Transmitted by Homologous Transfusions and Diseases They Cause

\begin{tabular}{|c|c|c|}
\hline Virus & Disease & Sequelae \\
\hline Cytomegalovirus (CMV) & $\begin{array}{l}\text { "Postperfusion syndrome" in } \\
\text { immunocompromised patients }\end{array}$ & Fever, jaundice, hepatosplenomegaly \\
\hline Non-A, Non-B hepatitis (NANB) & Hepatitis & $\begin{array}{l}\text { Liver enzymes increased } \\
\text { Cirrhosis } \\
\text { Chronic active hepatitis } \\
\text { Hepatoma }\end{array}$ \\
\hline $\begin{array}{l}\text { Human immunodeficiency } \\
\text { virus type } 1 \text { (HIV-1) }\end{array}$ & $\begin{array}{l}\text { Acquired immunodeficiency } \\
\text { syndrome }\end{array}$ & $\begin{array}{l}\text { Opportunistic infections } \\
\text { Kaposi's sarcoma } \\
\text { Lymphoma }\end{array}$ \\
\hline $\begin{array}{l}\text { Human T-cell leukemia virus } \\
\text { type } 1 \text { (HTLV-1) }\end{array}$ & T-cell leukemia/lymphoma & $\begin{array}{l}\text { Opportunistic infections/death } \\
\text { Gait and other movement } \\
\text { disorders }\end{array}$ \\
\hline $\begin{array}{l}\text { Human immunodeficiency virus } \\
\text { type } 2(\mathrm{HIV}-2)\end{array}$ & $\begin{array}{l}\text { Acquired immunodeficiency } \\
\text { syndrome }\end{array}$ & $\begin{array}{l}\text { Opportunistic infections } \\
\text { Kaposi's sarcoma } \\
\text { Lymphoma }\end{array}$ \\
\hline
\end{tabular}

The only method the clinician may have to diagnose NANB is long-term elevation of hepatic enzymes and findings of abnormality on liver biopsy in the absence of history of alcohol abuse, drug abuse, or other environmental agents that may account for the hepatic abnormality. It is now possible to screen for the presumptive agent (hepatitis $\mathrm{C}$ virus) responsible for NANB hepatitis, but the goal of a norisk blood supply remains elusive.

\section{Human immunodeficiency virus type 1}

The HIV-1 virus is the causative agent of the acquired immunodeficiency syndrome (AIDS), a deadly disease that causes the breakdown of the body's immune system, and a resultant opportunistic infection from which many do not recover. The disease usually is not diagnosed until an average of 3 years after the infected blood is transfused, although this period may be as long as 7 years. Persons receiving whole blood, as well as clotting factor concentrates, have detectable titers of antibody to HIV.

At present, all potential blood donors are screened and rejected if they are in any of the high-risk categories, such as an intravenous drug abuser or one who is promiscuous. Enzyme-linked immunosorbent assay (ELISA) is also used to detect antibodies to HIV in donated blood in case the donor "slipped by" the initial screening point. This mechanism does not ensure a "zero risk" blood supply because it does not catch the donors who are infected, but only those who are seronegative (absence of antibody to HIV-1) at the time of donation. Although the use of ELISA has greatly reduced the risk of acquiring AIDS through blood transfusion, it has not eliminated it completely.

\section{Human T-cell leukemia virus type 1}

The HTLV-type 1, like the HIV-1, is classified as a retrovirus. Also like HIV-1, it is a candidate for one of the transfusion-transmitted infectious diseases. The virus has been associated with adult T-cell leukemia/lymphoma in both Japan and the United States. It has also been associated with tropical spastic paresis in the Caribbean, and HTLV-1-associated myelopathy in Japan.

The leukemia/ymphoma is aggressive, characterized by organ invasion, circulating malignant $T$ cells, and a latency of approximately 30 years. Although the incidence of the disease is low in the United States, donated blood is screened for antibodies to HTLV-1. As with HIV-1 infection, some persons may be infected with the virus but are seronegative at the time of donation.

\section{Human immunodeficiency virus type 2}

Still another virus associated with blood transfusion is HIV-2, which can cause immunodefi- 
ciency and AIDS in a substantial proportion of those persons infected with the virus. Although the disease is more prevalent in West Africa, in this era of rapid global travel, it should not be presumed that this disease will remain endemic to West Africa. The disease has been identified in West Africans residing in the United States. An ELISA has been developed to detect antibodies to HIV-2; however, the possibility exists that an infected person has not seroconverted and thus would not be caught by the screening procedure.

\section{Autologous blood transfusions}

Because it is not possible to ensure a no-risk blood supply, persons undergoing elective surgery procedures who are concerned about contracting any of the low-risk-of-infusion-associated diseases may want to consider autologous blood transfusions rather than "taking chances" with homologous transfusions.

The indications for autologous blood transfusions set forth by the American Association of Blood Banks (AABB) are listed in Table 2. The primary reason for autologous blood transfusion is the prevention of transfusion-transmitted diseases that have been cited previously. An additional reason is the stockpiling of rare blood types. Other indications include preventing alloimmunization, which might put the patient at risk for transfusion reaction during or after future transfusions, preventing a transfusion reaction in those persons having a history of transfusion reaction and in those persons who have developed alloantibodies of any of the minor red blood cell (RBC) antigens. Further indications include the reduction of the risk of blood loss posed to those persons who cannot receive transfusions because of their religious beliefs, efforts to preserve the blood supply in isolated or remote communities that may not have ready access to adequate blood supplies.

Autologous blood transfusions may also be used to improve the intraoperative transfusion methods by using cell savers that will suction blood out of the operating field, filter it, wash it, and reinfuse it into the patient during surgery. Finally, autologous blood transfusion may also be indicated for replacing massive blood loss through devices such as the cell saver during intraoperative and postoperative periods.

Should any of the foregoing indications prevail, candidates for autologous blood transfusion can then progress to the next step in the

Table 2

Indications and Contraindications to Autologous Blood Donation, According to the American Association of Blood Banks

\section{Indications}

- Prevention of homologous transfusion-transmitted infections

- Stockpiling of rare blood types

- Prevention of alloimmunization

- Safe transfusion of patients with

history of transfusion reactions

- Avoidance of problems in patients with alloantibodies

- Means of permitting transfusion in patients whose religious doctrine forbids transfusion of another person's blood

- Maintenance of blood supply in isolated or remote communities

- Improvement of transfusion practice in selected surgical procedures

- Replacement of massive volume of intraoperative blood by means of intraoperative and postoperative blood salvage loss

\section{Contraindications}

- History of active epilepsy

- Acute cardiovascular or cerebrovascular disease (ie, dizziness, chest pain, seizures)

- Acute infection

- Unmonitored cardiac arrythmias

- Severely debilitating chronic disease

- Hemoglobin level $<11 \mathrm{~g} / \mathrm{L}$

- Hematocrit value $<33 \%$ 


\section{\#1 THERAPY FOR ROSACEA}

Un-retouched photographs from clinical studies, courtesy Arthur Sober, M.D.
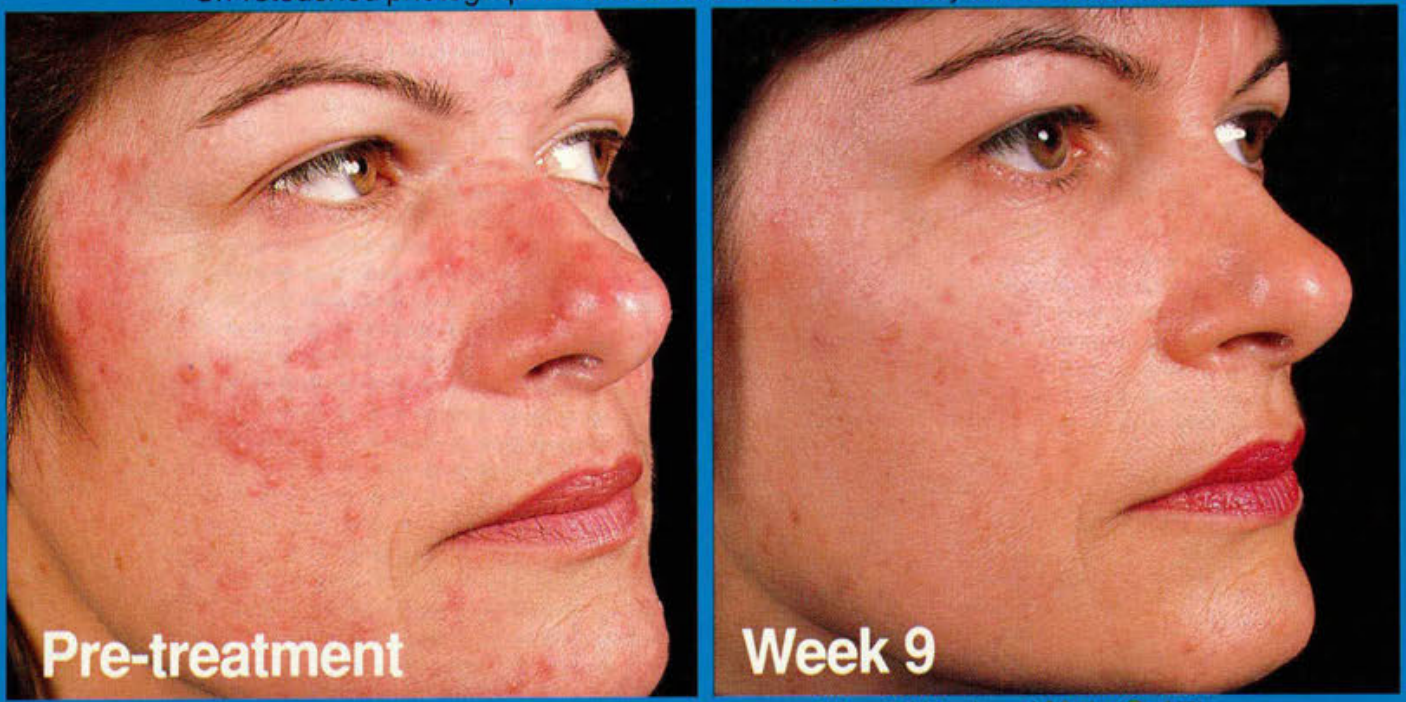

After 9 Weeks of MetroGel Therapy

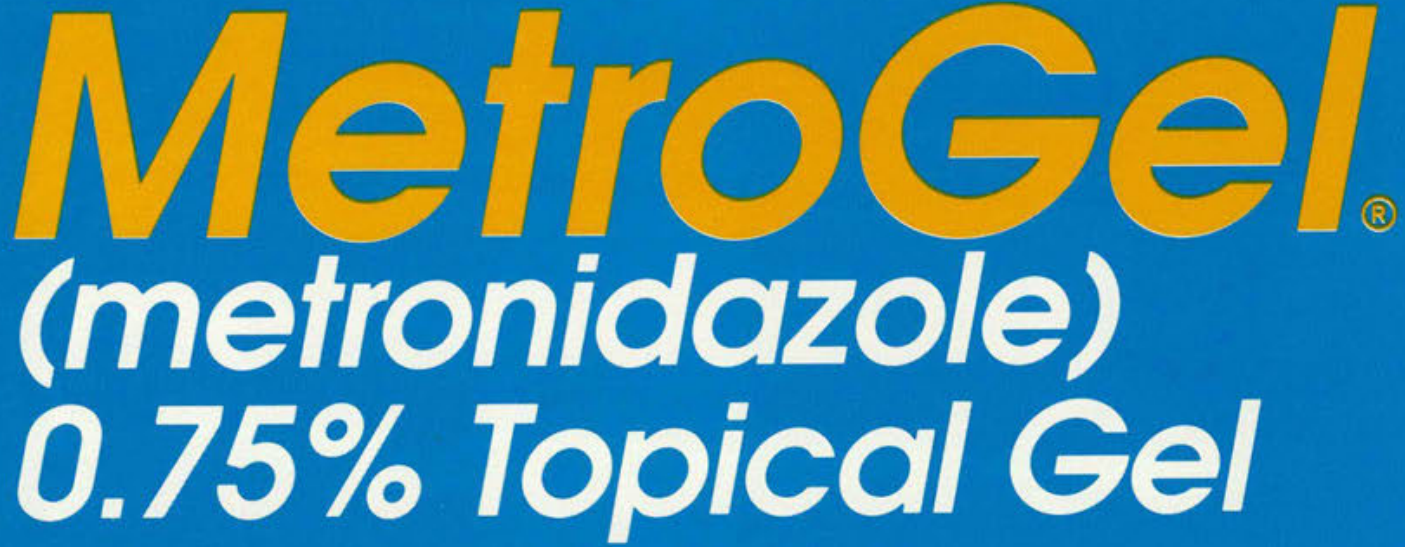

\section{PROVEN EFFECTIVE $2,3,4$}

- 9 weeks BID yields excellent initial efficacy. Some rosacea patients may see significant improvement within 3-6 weeks of MetroGel therapy

- Over $70 \%$ of patients experience significant reductions of papules, pustules and erythema

\section{EXCELLENT SAFETY PROFILE}

- No reports of systemic side effects

- Avoids common side effects associated with oral antibiotics, such as Gl distress, vaginal candidiasis and phototoxicity

\section{FORMULATED FOR PATIENT ACCEPTANCE}

- Elegant gel is $95 \%$ water and contains no oils, alcohols or fragrances

- MetroGel can be used under make-up, sunscreens or moisturizers

\section{CONVENIENT BID DOSING}

- Apply a thin film of MetroGel morning and evening

- Initial therapy for 9 weeks. Continued BID maintenance therapy as needed 


\section{Nol'\#1 THERAPY FOR ROSACEA'}

Un-retouched photographs from clinical studies, courtesy Arthur Sober, M.D.
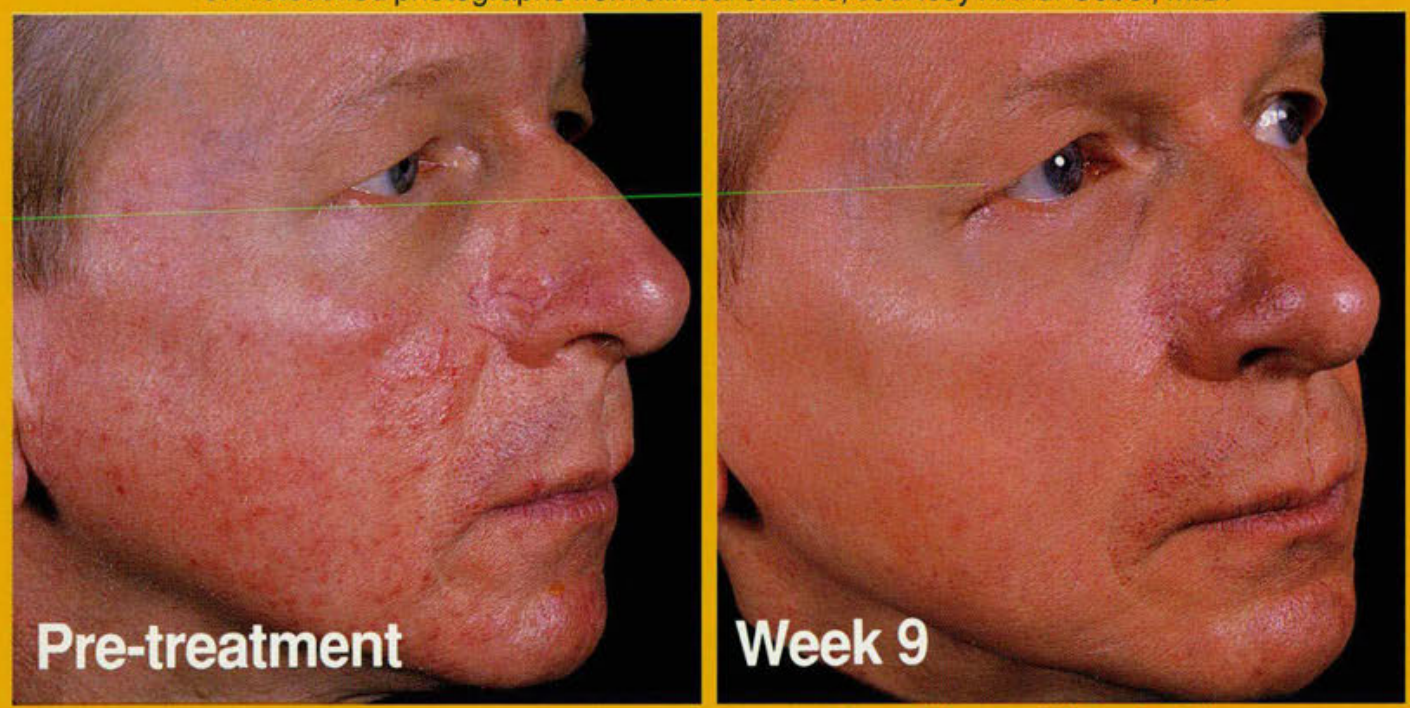

After 9 Weeks of MetroGel Therapy

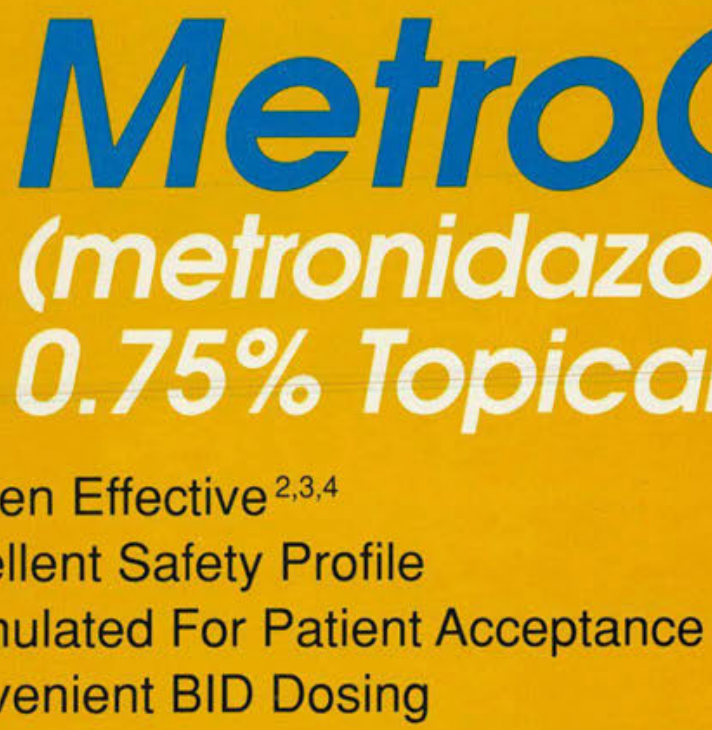

Briet Summary

MetroGel

(metronidazole) $0.75 \%$ Topical Gel

FOA TOPICAL USE ONLY

(NOT FOR OPHTHALMIC USE)

CLINICAL PHARMACOLOGY The mechanisms by which METROGEL acts in reducing inflammatory lesions of rosacea are unknown, but may include an ant-bacterial and/or an anti-inflammatory effect.

INDICATIONS AND USAGE METROGEL is indicated for topical application in the treatment of inflammatory papules, pustules, and erythema of rosacea

CONTRAINDICATIONS METROGEL is contraindicated in individuals with a history of hypersensitivity to metronidazole, parabens, or other ingre dients of the formulation

PRECAUTIONS Because of the minimal absorption of metronidazole and consequently its insignificant plasma concentration after topical adminis. tration, the adverse experiences reported with the oral form of the drug have not been reported with METROGEL.

General METROGEL has been reported to cause tearing of the eyes Therefore, contact with the eyes should be avoided. If a reaction suggesting ocal irritation occurs, patients should be directed to use the medication les frequentiy. discontinue use temporanily. Of discontinue use untir further in patients with evidence of, or history of, blood dyscrasia.

Drug Interactions Drug interactions are less likely with topical administra tion but should be kept in mind when METROGEL is prescribed for patients
Who are receiving anticoagulant treatment. Oral metronidazole has bee eported to potentiate the anticoagulant effect of coumarin and wartarin resulting in a prolongation of prothrombin time

Carcinogenesis: Tumorigenicity in Rodents Metronidazole has shown evidence of carcinogenic activity in a number of studies involving chronic, ora administration in mice and rats but not in studies involving hamsters. These studies have not been conducted with $0.75 \%$ metronidazole gel, which would result in significantly lower systemic blood levels than oral formulations.

Mutagenicity Studies Although metronidazole has shown mutagenic activity in a number of in vitro bacterial assay systems, studies in mamma (in vivo) have failed to demonstrate a potential for genetic damage.

Pregnancy This drug should be used during pregnancy only if clearly

Nursing Mothers Even though METROGEL blood levels are significantly lower than those achieved after oral metronidazole, a decision should be made whether to discontinue nursing or to discontinue the drug, taking into account the importance of the drug to the mother

Pediatric Use Safety and effectiveness in children have not been estabished.

ADVERSE REACTIONS Adverse conditions reported include waten (tearing) eyes if the gel is applied too closely to this area, transient redness. and mild dryness, burning, and skin irritation. None of the side effect exceeded an incidence of $2 \%$ of patients

DOSAGE AND ADMINISTRATION Apply and rub in a thin film of METROGEL twice daily morning and evening to entire affected areas atter METhOGEL twice daily, morning and evening, lo entire allected areas after washing. Significant therapeutic results should be noticed within three weeks. Clinicai studies
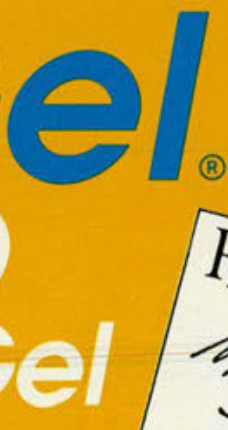

(B)

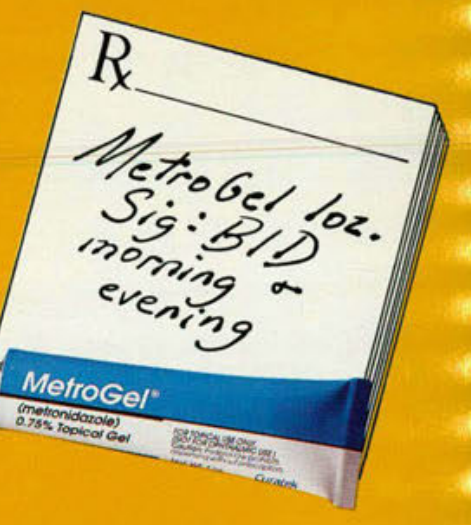


Volume Collected a.m. cc. p.m.

Phlebotomist's Initials p.m.

Tests to be done only if blood is not used by Autologous Donor and

Type \& RH Antibody Screen Pilot Seg

Anti-A

Anti-B

Anti-A, B

Anti-D

Rh Cont

Du

Du Cont

$\checkmark$ Cells

A, Cells

B Cells

Interp.

Initials

Date

Access

Labeled by

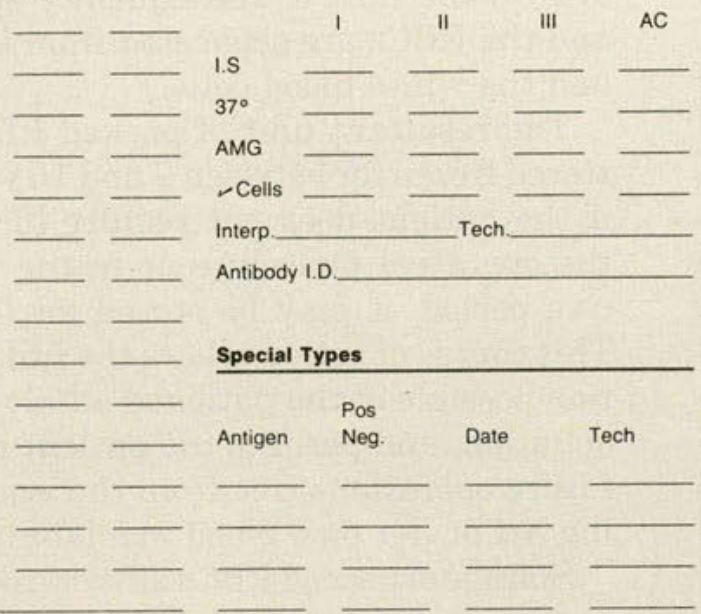

Preliminary Disposition

\begin{tabular}{l} 
Not for Transfusion \\
Autologous Only \\
Homologous \\
Final Disposition \\
\hline Given as whole blood \\
Date_ \\
Given as packed cells \\
Date_ \\
$\square$ Plasma, \\
$\square$ Single \\
Date_ Donor Plasma \\
Incinerated \\
$\square$ Whole \\
חPRBC \\
Date_ \\
Place
\end{tabular}

Test Interp. Tech.

RPR

ALT

HBs Ag

Hep B

Core $\mathrm{Ab}$

HTLVIII

Additional Information:
Autologous Donor

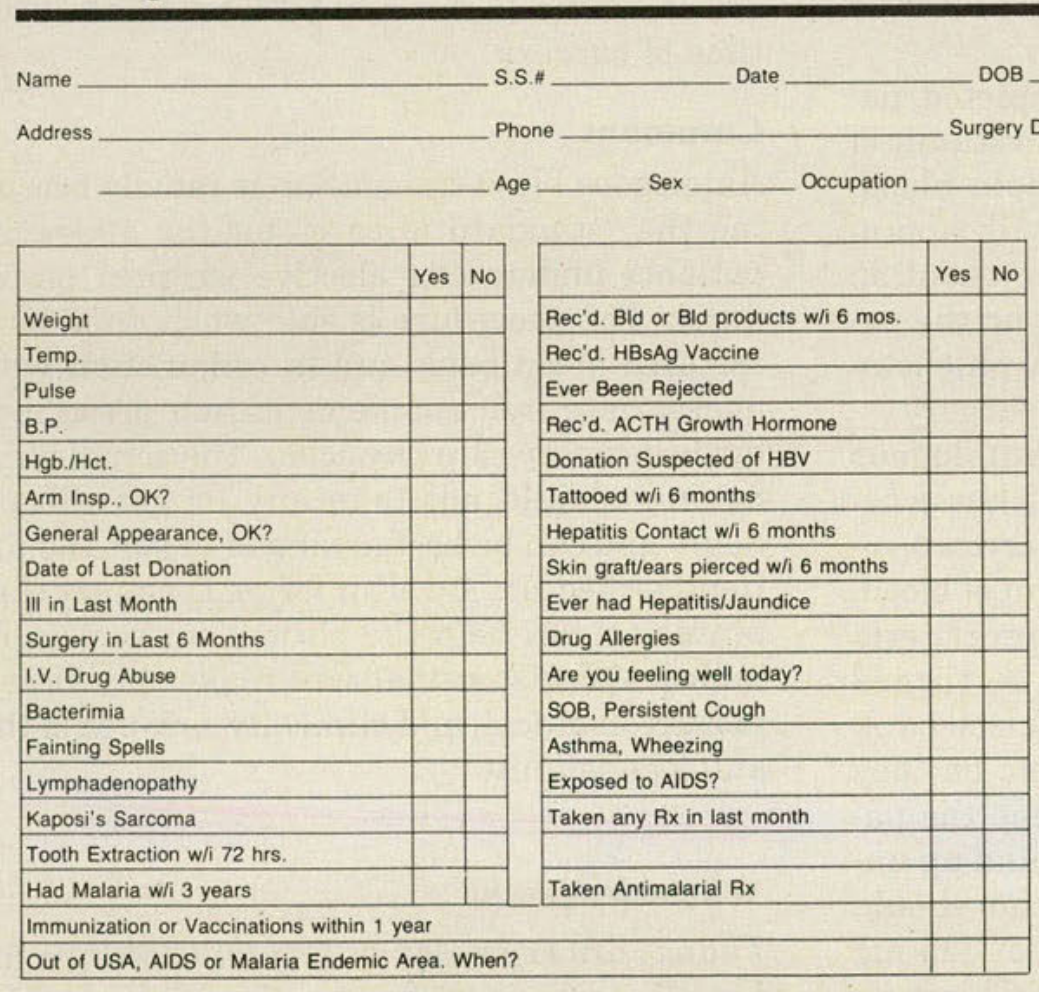

\begin{tabular}{|l|l|l|}
\hline & Yes & No \\
\hline Heart Disease & & \\
\hline Liver Disease & & \\
\hline History of Cancer & & \\
\hline Bleeding Tendency & & \\
\hline Convulsions & & \\
\hline White Spots/Blemishes in Mouth & & \\
\hline Pregnant Now - w/i 6 weeks & & \\
\hline Diabetes & & \\
\hline Tuberculosis & & \\
\hline Rheumatic Fever & & \\
\hline Undulant/Prolonged Fever & & \\
\hline Chest Pain & & \\
\hline Unexplained Weight Loss & & \\
\hline Nigh: Sweats & & \\
\hline Persistent Diarrhea & & \\
\hline & & \\
\hline & & \\
\hline Interviewer's Initials & & \\
\hline
\end{tabular}

Figure Sample information card for autologous blood donor. 
donation process. Patients must be thoroughly screened by means of a history and physical examination to ensure that the withdrawal of one unit of blood will not have a catastrophic physiologic consequence (Table 2). Generally,. to be eligible for autologous blood transfusion, patients should weigh more than 90 pounds $(40.8 \mathrm{~kg})$; should not have active epilepsy, acute cardiovascular or cerebrovascular disease (chest pain, dizziness, or seizures); acute infection; unmonitored arrhythmias; severely debilitating chronic disease; hemoglobin level lower than $11.0 \mathrm{~g} / \mathrm{dL}$; or hematocrit value less than $33 \%$. Any patient who is free of the aforementioned conditions can pass to the next step in the autologous blood transfusion process.

It is usually the primary care physicianwho has established rapport with the patientwho usually requisitions autologous blood donations at the hospital where the surgery is to be performed. The patient is given an appointment, during which the phlebotomist will meet with the patient and take a brief history and complete an information card similar to that in the Figure. Because the Food and Drug Administration has not yet approved placement of autologous units in the blood bank's general inventory, this question need not be asked.

Once the information card is completed, patient consent is obtained, and the first unit of blood can be drawn. Because whole blood, which is stored in a refrigerator with appropriate preservative, is good for only about 30 days, the clinician is advised to set up the patient's initial appointment with the phlebotomist no more than 30 days before surgery.

Patients who are making an autologous blood donation must wait at least 72 hours between donations to ensure adequate erythropoiesis. Each time patients donate a unit of blood, they must meet the AABB minimum criteria for blood donations, or they will be turned down by the medical director of the blood bank or the phlebotomist until such time as they meet those criteria. During the time the patient is donating autologous units, and up until surgery, the primary care physician should prescribe an iron supplementation of $325 \mathrm{mg}$ of iron three times a day with meals. This regi- men may result in poor patient compliance because of gastrointestinal upset, and thus may be tapered down to one or two tablets daily.

Because whole blood is rarely indicated as a replacement for intraoperative or postoperative blood loss, the primary care physician may wish to discuss autologous donations of packed RBCs. The patient has one unit of blood withdrawn; the unit is subsequently spun down, and the RBCs are separated from the plasma and the white blood cells.

The resultant unit of packed RBCs can be stored frozen for between 7 and 10 years; thus, if the patient does not require blood during the operative procedure or in the postoperative period, it may be stored for future use. This course of action allows the fullest utilization possible of the patient's autologous blood donation, and permits the patient to undergo future operations free from the worry of having his or her own blood available.

Storage of packed RBCs affords excellent preventive care for healthier patients who are middle-aged or elderly and are at high risk presently or may attain high risk status for hip fractures. The patient who is presently healthy could store blood for the time when the need arises and he or she may be debilitated at the time of surgery.

\section{Comment}

Autologous blood transfusion is rapidly becoming the "standard of care" for the 1990s for patients undergoing elective surgical procedures. The procedure is safe when done by a certified blood bank and in conjunction with appropriate iron supplementation prescribed by the primary care physician. The actual phlebotomy should not take any longer than 2 hours and can be best arranged to suit the patient's schedule. A well-informed primary care physician can help the patient make a wellinformed decision that will make the wisest, most economical, and clinically safe use of the autologous units.

\section{Acknowledgment}

Thanks are expressed to Mrs Ollie Margie for her assistance in the preparation of this article. 


\section{Bibliography}

American Association of Blood Banks: Cryopreservation of blood, in Technical Manual, ed 10. Arlington, Va, American Association of Blood Banks, 1990, pp 91-103.

American Association of Blood Banks: Autologous transfusions, in Technical Manual, ed 10. Arlington, Va, American Association of Blood Banks, 1990, pp 433-448.

Busch MP, Pekisen L, Schable C, et al: Monitoring blood donors for HIV-2 infection by testing anti-HIV-1 reactive sera, Transfusion 1990;30:184-187.
Committee on Technical Workshops, American Association of Blood Banks: Autologous Transfusions. Arlington, Va, American Association of Blood Banks, 1983.

Goodnough LT, Shuck JM: Risks, options, and informed consent for blood transfusion in elective surgery. Am J Surg 1990;159:602-609.

Groopman JE, Terry JA: A 34-year-old Jamaican man with fever, hepatic failure, diarrhea, and a progressive gait disorder. N Engl J Med 1989;321:663-675.

\section{HIV resource file AIDS/HIV hotlines}

$\square$ Centers for Disease Control National AIDS Hotline

1-800-342-AIDS (English)

1-800-344-SIDA (Spanish)

1-800-AIDS-TTY (Deaf Access)

(919) 361-8425 (Fax)

$\square$ National AIDS Clearinghouse

PO Box 6003

Rockville, MD 20849-6003

1-800-458-5231 (Reference Specialists)

(301) 217-0023 (International)

1-800-243-7012 (Deaf Access)

(301) 738-6616 (Fax)

\section{- Clinical Trials and Drug Information 1-800-TRIALS-A}

$\checkmark$ National Sexually Transmitted Diseases Hotline/American Social Health

Association 1-800-227-8922

$\square$ National Gay Task Force AIDS Information Hotline

1-800-221-7044

(212) 807-6016 (New York State)

\section{Information Sources}

\section{US Public Health Service Public Affairs Office}

Hubert H. Humphrey Building

Room 725-H

200 Independence Ave, SW

Washington, DC 20201

(202) 245-6867
Local Red Cross or American Red Cross

AIDS Education Office

1730 D St, NW

Washington, DC 20006

(202) $737-8300$

$\square$ American Association of Physicians

for Human Rights

PO Box 14366

San Francisco, CA 94114

(415) 558-9353

$\square$ AIDS Action Council

729 Eighth St, SE

Suite 200

Washington, DC 20003

(202) 547-3101

\section{Gay Men's Health Crisis}

PO Box 274

132 West 24th St

New York, NY 10011

(212) 807-6655

$\square$ Hispanic AIDS Forum

c/o APRED

853 Broadway

Suite 2007

New York, NY 10003

(212) $870-1902$ or $870-1864$

$\square$ Los Angeles AIDS Project

7362 Santa Monica Blvd

Los Angeles, CA 90046

(213) 876-AIDS

$\square$ Minority Task Force on Aids

c/o New York City Council of Churches

475 Riverside Dr, Rm 456

New York, NY 10115

(212) 749-1214 